\title{
Phytophthora mississippiae sp. nov., a New Species Recovered from Irrigation Reservoirs at a Plant Nursery in Mississippi
}

\author{
Xiao Yang ${ }^{1 *}$, Warren E Copes ${ }^{2}$ and Chuanxue Hong
}

${ }^{1}$ Department of Plant Pathology, Physiology and Weed Science, Hampton Roads Agricultural Research and Extension Center, Virginia Polytechnic Institute and State University, Virginia Beach, Virginia, USA

${ }^{2}$ Agricultural Research Service, US Department of Agriculture, Thad Cochran Southern Horticultural Laboratory, Poplarville, Mississippi, USA

\begin{abstract}
A previously unknown Phytophthora species was recovered from irrigation water in Mississippi. This novel species produced both nonpapillate and semipapillate sporangia, and catenulate hyphal swellings. All examined isolates were compatibility type A1. Ornamented oogonia with amphigynous antheridia and plerotic oospores were produced when this novel species was paired with A2 mating type testers of P. cryptogea and P. nicotianae in polycarbonate membrane tests. Sequence analyses of the rDNA internal transcribed spacer (ITS) region and the mitochondrially encoded cytochrome c oxidase 1 (cox 1) gene placed this species in clade 6 of the genus Phytophthora. Based on the morphological, physiological and molecular features, this new species is named as Phytophthora mississippiae sp. nov. The implications of these results are discussed.
\end{abstract}

Keywords: Phytophthora mississippiae; Irrigation reservoir; Ornamented oogonia

\section{Introduction}

The genus of Phytophthora was first described by Heinrich Anton de Bary in 1876 [1]. "Phytophthora" was from the Greek word " $\varphi v \tau o ́ v \varphi \theta o \rho a ́$ " which means "the plant-destroyer". The name evidences that Phytophthora genus includes a group of destructive plant pathogens. This genus was divided into 10 clades following phylogenetic analyses [2-4]. Among these clades, clade 6 has a strong association with forest and riparian environments [5]. It currently consists of 18 formal species. All were described after the year 2000, except for $P$. gonapodyides [6], $P$. humicola [7] and P. megasperma [8]. Clade 6 also includes a number of provisional species such as $P$. taxon forest soil, $P$. taxon oaksoil, and $P$. taxon Pgchlamydo [9], as well as many other undescribed taxa (Hong et al. unpublished).

Several factors have contributed to the recent increase in the number of species in clade 6. First, advancements in molecular biology and sequence analysis provide viable alternatives to morphospecies concepts used in traditional taxonomic systems such as the taxonomy key of Phytophthora species developed by Waterhouse [10]. Accompanying these advancements is identification of definitive characters and phylogenetic analysis tools that have greatly facilitated re-examination of Phytophthora collections and description of new species. For example, $P$. rosacearum and $P$. sansomeana were recently separated from the $P$. megasperma species complex after sequence analyses [11]. P. sp. O-group isolated in the 1990s was formally named as $P$. inundata [12]. P. taxon Salixsoil first isolated in the 1970s was assigned as $P$. lacustris [13]. Many newly isolated species in clade 6 such as P. bilorbang [14] and P. gemini [15] were also described by taking advantage of phylogenetic analysis. Second, recent occurrence of sudden oak death (SOD) caused by $P$. ramorum in the United States $[16,17]$ and forest declines caused by several Phytophthora species in other countries $[18,19]$ has motivated global surveys of natural habitats and waterways for these pathogens. These surveys done in natural environments recovered a number of new species such as $P$. borealis and $P$. riparia [20], plus other taxa that belong to clade 6 . Third, parallel surveys of irrigation systems have been greatly intensified to address growing concerns over the increasing Phytophthora disease risk as agricultural industries increasingly use recycled water in the light of global water scarcity $[21,22]$. The surveys in irrigation systems also recovered a number of novel Phytophthora species [23-25] and many new taxa in clade 6 (Hong et al. unpublished).

The objective of this study was to characterize and describe a group of isolates belonging to a previously unknown Phytophthora species recovered from irrigation reservoirs in Mississippi. We describe the morphological, physiological and molecular characters of this new taxon and formally name it as Phytophthora mississippiae sp. nov.

\section{Materials and Methods}

\section{Isolation and isolate maintenance}

The origin of four Phytophthora mississippiae isolates examined in this study is shown in Table 1 . They were recovered from the surface, middle, or bottom of water columns in irrigation reservoirs at an ornamental plant nursery of Mississippi in 2012 by baiting with rhododendron leaves [26,27]. These baits were deployed in the surveyed reservoirs for 7 days then transferred to a laboratory. They were then cut into approximately $3 \times 3 \mathrm{~cm}^{2}$ sections and plated onto PARP selective media (contains pimarcin, ampicillin, rifampicin, and pentachloronitrobenzene). Phytophthora colonies emerging from the edge of baits were hyphal-tipped onto $20 \%$ clarified V8 juice agar (CV8A) to obtain pure cultures [1]. Cultures were maintained on CV8A and blocks of fresh agar cultures were transferred into microtubes with sterile distilled water for long-term storage at $15^{\circ} \mathrm{C}$. The holotype isolate

*Corresponding author: Xiao Yang, Department of Plant Pathology, Physiology and Weed Science, Hampton Roads Agricultural Research and Extension Center, Virginia Polytechnic Institute and State University, Virginia Beach, Virginia, USA; E-mail: yxiao9@vt.edu

Received May 27, 2013; Accepted June 18, 2013; Published June 24, 2013

Citation: Yang X, Copes WE, Hong C (2013) Phytophthora mississippiae sp. nov., a New Species Recovered from Irrigation Reservoirs at a Plant Nursery in Mississippi. J Plant Pathol Microb 4: 180 doi:10.4172/2157-7471.1000180

Copyright: @ 2013 Yang X, et al. This is an open-access article distributed under the terms of the Creative Commons Attribution License, which permits unrestricted use, distribution, and reproduction in any medium, provided the original author and source are credited. 
Citation: Yang X, Copes WE, Hong C (2013) Phytophthora mississippiae sp. nov., a New Species Recovered from Irrigation Reservoirs at a Plant Nursery in Mississippi. J Plant Pathol Microb 4: 180 doi:10.4172/2157-7471.1000180

Page 2 of 7

\begin{tabular}{|c|c|c|c|c|c|c|c|}
\hline \multirow[t]{2}{*}{ Species } & \multirow[t]{2}{*}{ ITS clade } & \multirow[t]{2}{*}{ Isolate } & \multirow[t]{2}{*}{ Location } & \multirow[t]{2}{*}{ Substrate } & \multirow[t]{2}{*}{ Date } & \multicolumn{2}{|c|}{ GenBank accession no. } \\
\hline & & & & & & ITS & $\operatorname{cox} 1$ \\
\hline \multirow[t]{4}{*}{ Phytophthora mississippiae } & 6 & $57 J 1$ & Mississippi, USA & Irrigation water & 2012 & KF112850 & KF112858 \\
\hline & & $57 \mathrm{~J} 2$ & Mississippi, USA & Irrigation water & 2012 & KF112851 & KF112859 \\
\hline & & $57 \mathrm{~J}^{\top}$ & Mississippi, USA & Irrigation water & 2012 & KF112852 & KF112860 \\
\hline & & $57 J 4$ & Mississippi, USA & Irrigation water & 2012 & KF112853 & KF112861 \\
\hline P. amnicola & 6 & $\mathrm{DH} 228$ & Australia & Still water & 2009 & JQ029956 & JQ029948 \\
\hline \multirow[t]{2}{*}{ P. asparagi } & 6 & SP326 & Michigan, USA & Asparagus officinalis & 2008 & EF185089 & $n / a^{*}$ \\
\hline & & CBS121536 & The Netherlands & Asparagus officinalis & $\mathrm{n} / \mathrm{a}$ & $\mathrm{n} / \mathrm{a}$ & JX524163 \\
\hline P. bilorbang & 6 & CBS161653 & Australia & $\begin{array}{l}\text { Rhizosphere soil of dying } \\
\text { Rubus sp. }\end{array}$ & 2012 & JQ256377 & JQ256375 \\
\hline P. borealis & 6 & AKWA58.1-0708 & Alaska, USA & Creek water & 2012 & HM004232 & JQ626625 \\
\hline P. fluvialis & 6 & MURU 468 & Australia & River water & 2009 & JF701436 & JF701442 \\
\hline P. gemini & 6 & CBS123381 & The Netherlands & Zostera marina & 1998 & FJ217680 & JX262931 \\
\hline P. gibbosa & 6 & CBS127951 & Australia & $\begin{array}{l}\text { Root soil of dying Acacia } \\
\text { pycnantha }\end{array}$ & 2009 & HQ012933 & HQ012846 \\
\hline P. gonapodyides & 6 & 34A8, CBS55467 & United Kingdom & Fruit bait & 1967 & KF112854 & KC733448 \\
\hline P. gregata & 6 & CBS127952 & Australia & $\begin{array}{l}\text { Root soil of dying } \\
\text { Patersonia sp. }\end{array}$ & 2009 & HQ012942 & HQ012858 \\
\hline P. humicola & 6 & 32F8, P3826 & Taiwan & Soil slurries & 1977 & KF112855 & KF112862 \\
\hline P. inundata & 6 & 30J3, P894 & Spain & Olea roots & 1966 & KF112856 & KF112863 \\
\hline P. lacustris & 6 & P245 & United Kingdom & Salix matsudana & 1972 & AF266793 & JF896561 \\
\hline P. litoralis & 6 & CBS127953 & Australia & $\begin{array}{l}\text { Root soil of dying Banksia } \\
\text { sp. }\end{array}$ & 2008 & HQ012948 & HQ012866 \\
\hline \multirow[t]{2}{*}{ P. megasperma } & 6 & CBS40272 & $\begin{array}{l}\text { Washington, D.C., } \\
\text { USA }\end{array}$ & Althaea rosea & 1931 & HQ643275 & $\mathrm{n} / \mathrm{a}$ \\
\hline & & IMI133317 & Australia & $n / a$ & 1968 & $\mathrm{n} / \mathrm{a}$ & AY564194 \\
\hline P. pinifolia & 6 & CMW26668 & Chile & Pinus radiata & 2007 & EU725806 & JN935961 \\
\hline P. riparia & 6 & 3-100B9F & Oregon, USA & Creek water & 2006 & HM004225 & $\mathrm{n} / \mathrm{a}$ \\
\hline P. rosacearum & 6 & 22J9, OSU 62 & California, USA & Cherry & $\mathrm{n} / \mathrm{a}$ & KF112857 & KF112864 \\
\hline P. thermophila & 6 & CBS127954 & Australia & $\begin{array}{l}\text { Root soil of dying } \\
\text { Eucalyptus sp. }\end{array}$ & 2004 & EU301155 & HQ012872 \\
\hline P. infestans & 1 & 27A8, KDT-2C & Mexico & Solanum tuberosum & 1992 & KC733443 & KC733447 \\
\hline P. meadii & 2 & CBS21988 & India & Hevea brasiliensis & 1987 & HQ643268 & AY564192 \\
\hline P. sojae & 7 & 28F9, P6497 & Mississippi, USA & Glycine max & 1974 & KC733444 & AY564162 \\
\hline P. lateralis & 8 & $\begin{array}{l}\text { IMI040503, } \\
\text { CBS16842 }\end{array}$ & Oregon, USA & Chamaecyparis lawsoniana & 1942 & AF266804 & AY564191 \\
\hline$P$. aquimorbida & 9 & $40 \mathrm{~A} 6$ & Virginia, USA & irrigation reservoir & 2006 & FJ666127 & GQ294536 \\
\hline P. macrochlamydospora & 9 & 33E1, P10264 & Australia & Glycine max & 2003 & KC733445 & KC733454 \\
\hline \multirow[t]{2}{*}{ Pythium aphanidermatum } & Pythium & P1779 & $n / a$ & $n / a$ & $\mathrm{n} / \mathrm{a}$ & GU983641 & $\mathrm{n} / \mathrm{a}$ \\
\hline & & $\mathrm{P} 2$ & $\mathrm{n} / \mathrm{a}$ & $\mathrm{n} / \mathrm{a}$ & $\mathrm{n} / \mathrm{a}$ & $\mathrm{n} / \mathrm{a}$ & AY564163 \\
\hline
\end{tabular}

Texo-type

*n/a=not available

Table 1: Origin and GenBank accession numbers of Phytophthora mississippiae isolates and reference species.

MYA-4946 was deposited at the American Type Culture Collection in Manassas, Virginia, USA.

\section{Colony morphology and cardinal temperatures}

Ten-day-old colony morphology of the four isolates of $P$. mississippiae on carrot agar (CA), CV8A, malt extract agar (MEA), and potato dextrose agar (PDA) grown at $20^{\circ} \mathrm{C}$ in the dark was noted and photographed.

Cardinal temperatures of the four isolates were assessed on CV8A and CA. Agar blocks (5 $\mathrm{mm}$ in diameter) taken from actively growing areas of 7-day-old cultures were placed on fresh media at the center of 10-cm Petri dishes. Triplicate Petri dishes per isolate per temperature were placed in the dark at $5,10,15,20,25,30,35$, and $40^{\circ} \mathrm{C}$. Two perpendicular measurements of each colony were taken after 8 days. This test was repeated. Following the analysis of variance using $\mathrm{R}$ statistical software v. 2.15.0 [28], data from repeating tests were pooled together. Radial growths along with their standard errors were plotted against temperature using the gplots package v. 2.11.0 [29] in R.

\section{Morphology of sporangia and gametangia}

Sporangia were produced by transferring agar plugs $\left(10 \times 10 \mathrm{~mm}^{2}\right)$ from actively growing area of 10-day-old cultures on CV8A to Petri dishes containing non-sterile, $1.5 \%$ soil water extract solution (SWE, $15 \mathrm{~g}$ of sandy loam soil/1 L distilled water) or filtered, non-sterile pond water. Mature sporangia developed after incubating at room temperature $\left(\right.$ c. $\left.23^{\circ} \mathrm{C}\right)$ under cool-white fluorescent light.

Mating type of these isolates was determined by placing each with an A1 or A2 mating type tester of P. cinnamomi in dual cultures on hemp seed agar (HSA). Selfed sexual structures were produced at room temperature using the polycarbonate membrane method to physically separate P. mississippiae isolates from their reverse mating type testers [30,31]. Several heterothallic species including P. cinnamomi, $P$. 
Citation: Yang X, Copes WE, Hong C (2013) Phytophthora mississippiae sp. nov., a New Species Recovered from Irrigation Reservoirs at a Plant Nursery in Mississippi. J Plant Pathol Microb 4: 180 doi:10.4172/2157-7471.1000180

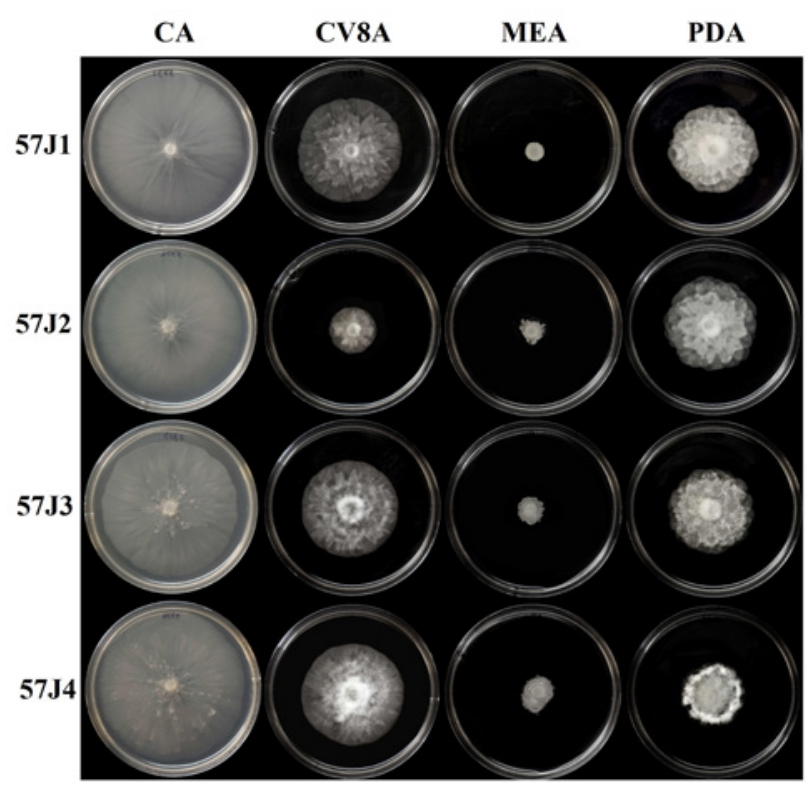

Figure 1: Colony morphology of Phytophthora mississippiae isolates on various media incubated at $20^{\circ} \mathrm{C}$ for 10 days in the dark: $C A=$ carrot agar; $C V 8 A=20 \%$ clarified $V 8$ juice agar; MEA=malt extract agar; PDA=potato dextrose agar.
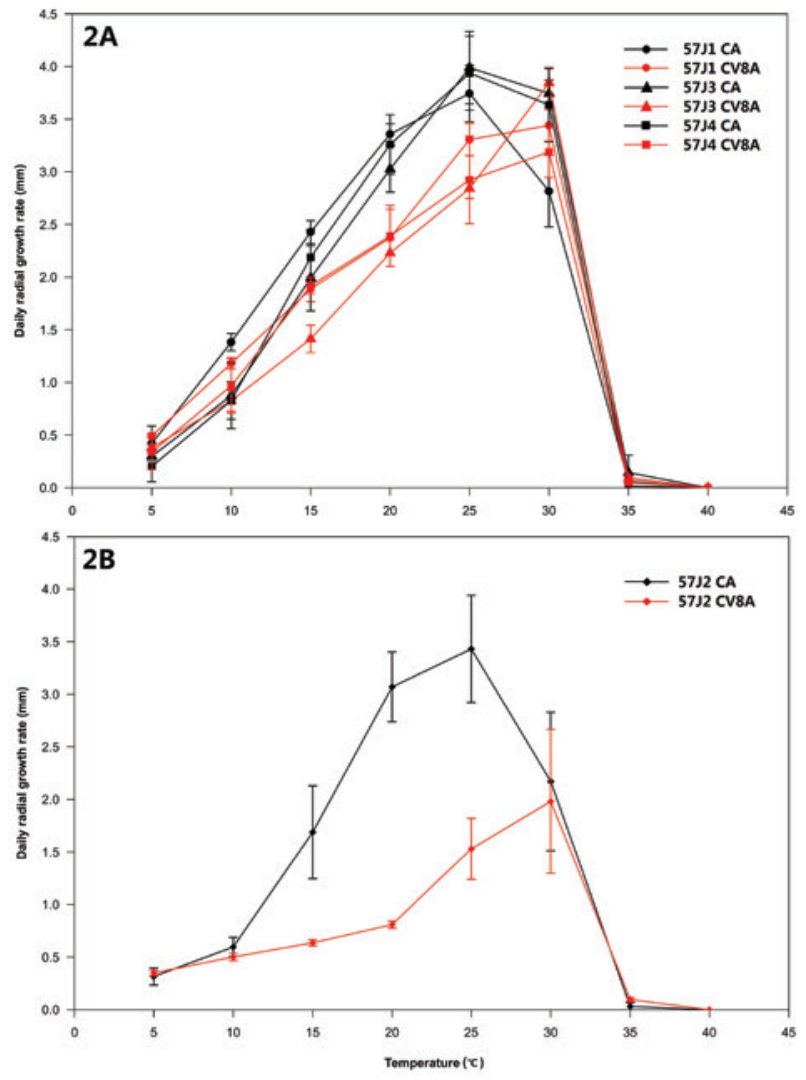

Figure 2: Differential radial growth of Phytophthora mississippiae isolates on carrot agar (CA) and $20 \%$ clarified V8 juice agar (CV8A): A. Daily radial growth rates of isolates $57 \mathrm{~J} 1,57 \mathrm{~J} 3$, and $57 \mathrm{~J} 4 ; \mathrm{B} .57 \mathrm{~J} 2$.

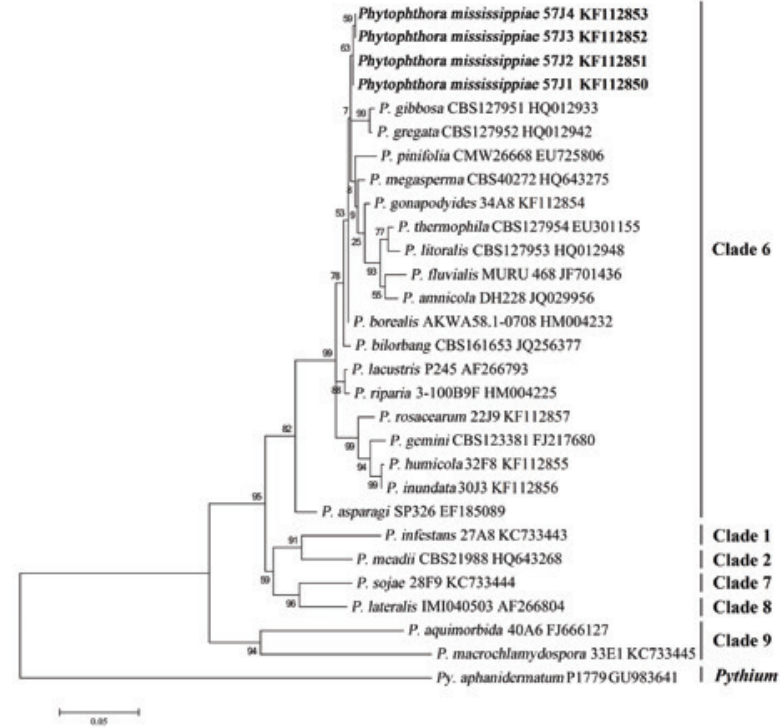

Figure 3: A maximum likelihood phylogenetic tree generated in MEGA 5.1, based on the alignment of ITS sequences with Clustal $X$. The numbers on branches are bootstrap values (1,000 replicates; values less than $50 \%$ are not shown).

cambivora, P. meadii, P. nicotianae, and P. cryptogea were used as mating type testers.

Sporangia and gametangia were photographed with a Nikon Fujix Digital Camera HC-300Zi connected to a Nikon Labophot-2 microscope. Fifty randomly selected mature sporangia were measured for length and width while 30 gametangia were measured for the size of oogonia, oospores, and antheridia with Image-Pro ${ }^{\circledR}$ Plus v. 5.1.2.53.

\section{DNA extraction, amplification and sequencing}

Isolates were grown in 20\% V8 juice broth at room temperature for one week. Mycelial masses were harvested and lysed using a FastPrep ${ }^{\circledR}-24$ system (MP Biomedicals, Santa Ana, CA). DNA was extracted as instructed using the DNeasy ${ }^{\circledR}$ Plant Mini kit (Qiagen, Valencia, CA). Amplifications were performed with forward primer ITS6 and reverse primer ITS4 [2] for the internal transcribed spacer (ITS) region covering ITS1, 5.8S rRNA gene, and ITS2, following previously described reaction mix recipe and PCR program [32]. Primer pair COX4FR was used to amplify the mitochondrial cytochrome $c$ oxidase 1 ( $\operatorname{cox} 1)$ gene [3]. Sequencing was performed in both directions at the University of Kentucky Advanced Genetic Technologies Center (Lexington, KY) using the same primers. Sequences of both directions were visualized with Finch TV v. 1.4.0. and aligned using Clustal W.

\section{Sequence analyses}

Sequences generated in this study were compared with those of all other species in the same clade and species representing other clades (Table 1). Sequences were aligned using Clustal W. Phylogeny reconstruction was conducted in MEGA 5.1 [33] using the Maximum Likelihood method based on the Tamura-Nei model [34] with 1,000 replications of bootstrap.

\section{Results}

\section{Colony morphology}

The four isolates of $P$. mississippiae had a similar growth pattern at 
Citation: Yang X, Copes WE, Hong C (2013) Phytophthora mississippiae sp. nov., a New Species Recovered from Irrigation Reservoirs at a Plant Nursery in Mississippi. J Plant Pathol Microb 4: 180 doi:10.4172/2157-7471.1000180

Page 4 of 7

\begin{tabular}{|c|c|c|c|c|c|c|c|c|c|c|c|c|c|c|c|c|}
\hline \multirow[t]{2}{*}{ Isolate } & \multicolumn{6}{|c|}{ ITS1 } & \multicolumn{10}{|c|}{ ITS2 } \\
\hline & 15 & 43 & 44 & 98 & 106 & 173 & 469 & 517 & 553 & 582 & 588 & 608 & 652 & 740 & 744 & 787 \\
\hline & \multicolumn{6}{|c|}{ Phytophthora mississippiae } & & & & & & & & & & \\
\hline 57J1, 57J2 & A & $\mathrm{T}$ & A & C & A & C & C & $\mathrm{T}$ & C & G & G & C & $\mathrm{T}$ & $\mathrm{T}$ & G & - \\
\hline \multirow[t]{2}{*}{$57 \mathrm{~J} 3,57 \mathrm{~J} 4$} & A & $\mathrm{T}$ & A & C & G & $\mathrm{T}$ & $\mathrm{T}$ & $\mathrm{T}$ & C & G & G & C & $\mathrm{T}$ & $\mathrm{T}$ & G & - \\
\hline & \multicolumn{6}{|c|}{ Phytophthora borealis } & & & & & & & & & & \\
\hline \multirow[t]{2}{*}{ AKWA58.1-0708 } & - & $\mathrm{T}$ & A & $\mathrm{Y}$ & G & C & $\mathrm{T}$ & $\mathrm{T}$ & C & S & G & $\mathrm{Y}$ & G & G & G & - \\
\hline & \multicolumn{6}{|c|}{ Phytophthora gonapodyides } & & & & & & & & & & \\
\hline 34A8 & A & A & $\mathrm{T}$ & C & G & $\mathrm{T}$ & $\mathrm{T}$ & G & $\mathrm{T}$ & G & A & C & G & $\mathrm{T}$ & A & $\mathrm{T}$ \\
\hline
\end{tabular}

Table 2: Polymorphic nucleotides in the sequences of internal transcribed spacer region (ITS) among Phytophthora mississippiae isolates and the type isolates of $P$. borealis and $P$. gonapodyides. Compared to the sequence of $P$. mississippiae type isolate $57 \mathrm{~J} 3$, the differential nucleotides of isolates $57 \mathrm{~J} 1$ and $57 \mathrm{~J} 2$, $P$. borealis, and $P$. gonapodyides are shaded.

\begin{tabular}{|c|c|c|c|c|c|}
\hline \multirow[t]{2}{*}{ Character } & \multicolumn{4}{|c|}{ Isolate } & \multirow[t]{2}{*}{ Species average } \\
\hline & $57 J 1$ & $57 \mathrm{~J} 2$ & $57 \mathrm{~J} 3$ & $57 J 4$ & \\
\hline \multicolumn{6}{|l|}{ Shape (\%) } \\
\hline ovoid to obpyriform & 86 & 93 & 96 & 90 & 92 \\
\hline slightly ellipsoid & 12 & 7 & 4 & 2 & 6 \\
\hline distorted & 1 & - & - & 8 & 2 \\
\hline \multicolumn{6}{|l|}{ Papilla (\%) } \\
\hline nonpapillate & 66 & 70 & 53 & 69 & 64 \\
\hline semipapillate & 33 & 30 & 47 & 31 & 36 \\
\hline Size range $(\mu \mathrm{m})$ & $47.3-70.0 \times 21.1-43.3$ & $48.8-64.3 \times 26.8-38.6$ & $55.4-71.9 \times 28.6-41.9$ & $47.3-77.3 \times 20.4-37.1$ & $47.3-77.3 \times 20.4-43.3$ \\
\hline Average size $(\mu \mathrm{m})$ & $61.5 \pm 7.2 \times 34.0 \pm 3.5$ & $57.4 \pm 3.9 \times 31.1 \pm 2.5$ & $62.6 \pm 3.8 \times 34.9 \pm 3.2$ & $60.3 \pm 7.2 \times 26.8 \pm 3.4$ & $60.4 \pm 6.0 \times 31.3 \pm 4.5$ \\
\hline $\mathrm{L}: \mathrm{W}$ ratio & 1.82 & 1.85 & 1.80 & 2.27 & 1.96 \\
\hline
\end{tabular}

Table 3: Morphological variations of sporangial characters among isolates of Phytophthora mississippiae in this study.

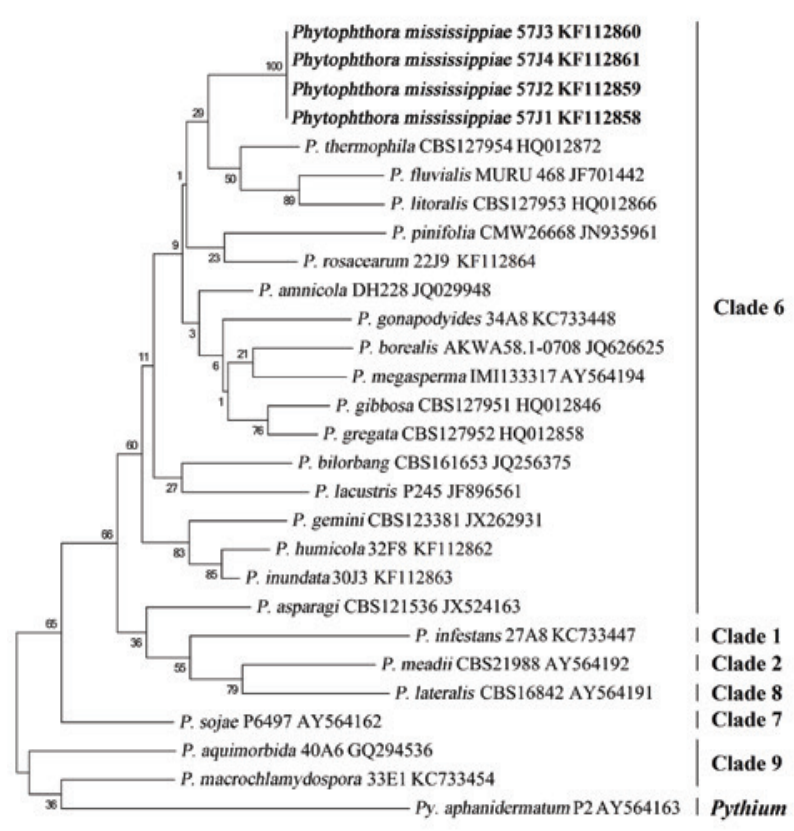

$\longmapsto 0.1$

Figure 4: A maximum likelihood phylogenetic tree generated in MEGA 5.1 based on the alignment of partial cox 1 sequence with Clustal $X$. The numbers on branches are bootstrap values (1,000 replicates; values less than $50 \%$ are not shown).

$20^{\circ} \mathrm{C}$ on each medium (Figure 1). Colonies had none to sparse aerial mycelia and grew at the greatest rates on CA. The colony pattern on
CA was radiate with a smooth edge. Isolates 57J1, 57J3 and 57J4 had a moderate growth rate on CV8A while isolate 57J2 had a slow growth rate. All isolates produced hispid aerial mycelia. Colony pattern on CV8A was radiate to slightly petaloid with a relatively smooth edge. On MEA, all isolates had limited but discernible growth with irregular colony patterns. Isolates had a moderate growth rate on PDA and produced tomentose aerial mycelia. Colony pattern on PDA was petaloid (isolates 57J1, 57J2 and 57J3) to slight cottony (isolate 57J4).

\section{Cardinal temperatures for vegetative growth}

Radial growth rates were different among isolates $(P<0.01)$ but not between repeating experiments $(P=0.17)$. Isolates $57 \mathrm{~J} 1,57 \mathrm{~J} 3$, and $57 \mathrm{~J} 4$ had similar growth rates (Figure $2 \mathrm{~A}$ ). Isolate $57 \mathrm{~J} 2$ grew more slowly than the other isolates at 10 to $30^{\circ} \mathrm{C}$ on both CV8A and CA (Figure 2B). The optimum temperature for the growth of $P$. mississippiae was $25^{\circ} \mathrm{C}$ on CA and $30^{\circ} \mathrm{C}$ on CV8A. Limited but notable growth was observed at 5 and $35^{\circ} \mathrm{C}$. No growth occurred at $40^{\circ} \mathrm{C}$. After the experiments were completed, cultures from all temperatures were relocated to room temperature. Additional growth occurred on plates previously maintained at $5^{\circ} \mathrm{C}$ but not those maintained at $40^{\circ} \mathrm{C}$.

\section{Sequence analyses and phylogenetic position}

GenBank accession numbers of sequences generated in this study and used in the sequence analyses are shown in table 1. All isolates of $P$. mississippiae have 818 bp ITS sequences. Isolates 57J1 and 57J2 have an identical ITS sequence, while 57J3 and 57J4 have an identical ITS sequence (Table 2). These two subgroups differ by $3 \mathrm{bp}$. These ITS sequences of $P$. mississippiae were distinct from those of all known Phytophthora species. Two species with most similar ITS sequences are 

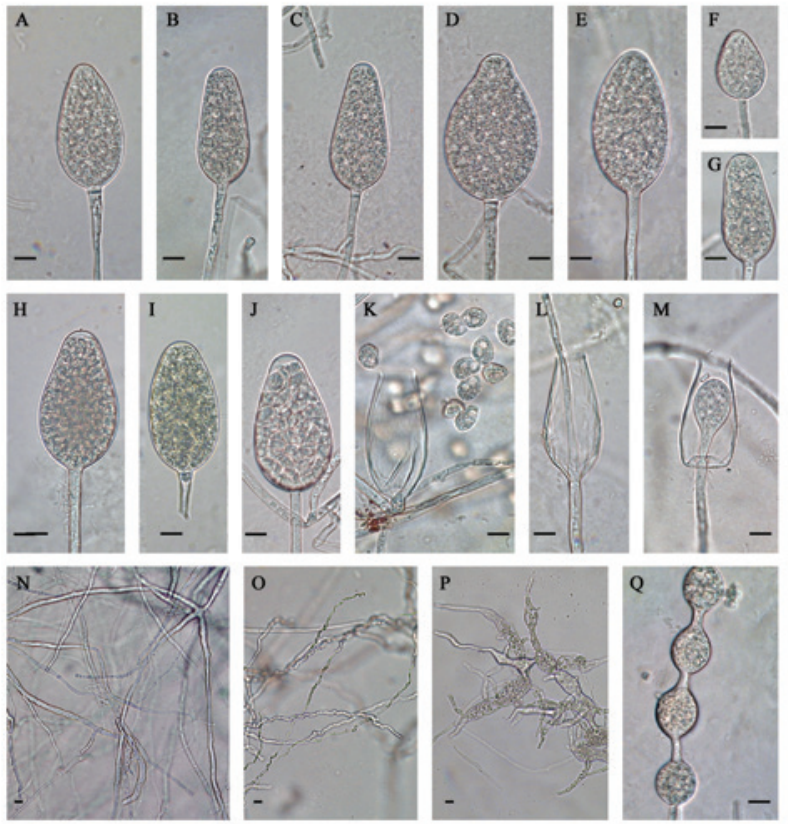

Figure 5: Morphology of asexual structures of Phytophthora mississippiae: A-G) Nonpapillate, noncaducous sporangia in various shapes; A) An obpyriform to ovoid sporangium; B, C:0Obpyriform sporangia; D) An ovoid sporangium; E) An slightly excentric, ellipsoid sporangium; F) A secondary, ovoid sporangium; G)A secondary, obpyriform sporangium; H)A semipapillate, ovoid sporangium; I) A semipapillate, ellipsoid sporangium; J) A semipapillate sporangium right before releasing zoospores; K) A sporangium releasing zoospores; L) Internal extended proliferation; M) Nesting proliferation; N) Smooth, flat mycelia; O) Coiled mycelia; P) Swollen mycelia; Q) Catenulate hyphal swellings.

Bars $=10 \mu \mathrm{m}$.
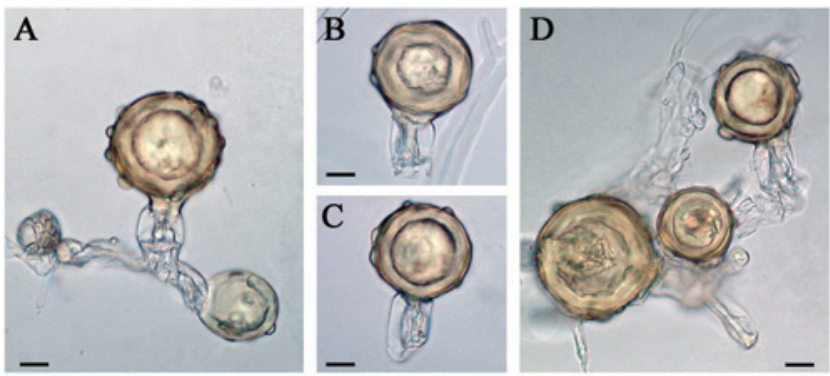

Figure 5: Morphology of gametangia of Phytophthora mississippiae: A, B) Selfing gametangia induced by P. cryptogea; A) An oogonium with an ornamented surface and a tapered base, a bi-celled, amphigynous antheridium, and two immature gametangia; B) An oogonium with ornamented surface and tapered base; C, D) Selfing gametangia induced by P. nicotianae; C) A plerotic oospore with a cylindroid, amphigynous antheridium; D) Three different sized oogonia.

Bars $=10 \mu \mathrm{m}$.

P. borealis and P. gonapodyides. P. mississippiae differs from $P$. borealis (GenBank accession no. HM004232) and P. gonapodyides (GenBank accession no. KF112854) in the ITS sequence by 7 and 8 bp, respectively (Table 2).

The four P. mississippiae isolates have an identical 867 bp cox 1 sequence, which also is distinct from those of all known species. The cox 1 sequence of $P$. mississippiae differs from two proximal sequences, those of P. thermophila (GenBank accession no. HQ012872) and P. borealis (GenBank accession no. JQ626625) by 30 and 31 bp, respectively.

Sequence analyses of both ITS and cox 1 sequences placed $P$. mississippiae in clade 6 of the genus Phytophthora [5,9]. The four $P$. mississippiae isolates form a distinct taxon in the phylogenetic trees based on ITS (Figure 3) and cox 1 (Figure 4) sequences.

\section{Taxonomy}

Phytophthora mississippiae X. Yang, W. E. Copes, and C. X. Hong., sp. nov.-MycoBank MB804659; Figures 1, 5A-Q, 6A-D.

Phytophthora mississippiae produced abundant sporangia in $1.5 \%$ SWE after 15 hours under light. Sporangia were mostly ovoid to obpyriform (Figures 5A-D, F-H, J). It occasionally produced slight ellipsoid sporangia (Figures 5E, I). Sporangia were noncaducous, mostly nonpapillate (Figures $5 \mathrm{~A}-\mathrm{G}$ ) and sometimes semipapillate (Figures 5H-J). Primary sporangia were terminal and averaged 60.5 $\mu \mathrm{m}$ in length and $31.7 \mu \mathrm{m}$ in width. Secondary lateral sporangia were observed on the mycelial plug after submersion in SWE for more than 40 hours. Nested and extended internal proliferation was common (Figures 5L, M). Sporangial characteristics among four P. mississippiae isolates are summarized in table 3. Mycelia were flat (Figure $5 \mathrm{~N}$ ), coiled (Figure 5O), or swollen (Figure 5P). Hyphal swellings were commonly elongated with irregular shapes, especially in aged cultures $(>30$-dayold). Catenulate, globose hyphal swellings were frequently observed in both fresh and aged cultures (Figure 5Q). Chlamydospores were not observed.

Phytophthora mississippiae is self-sterile. Gametangia were produced in dual cultures where P. mississippiae isolates were paired with an A2 mating type tester of $P$. cinnamomi suggesting that all four isolates examined in this study are A1. In the polycarbonate membrane test, gametangia were produced by isolates $57 \mathrm{~J} 3$ and $57 \mathrm{~J} 4$ after 50-day-breeding when paired with A2 mating type testers of $P$. cryptogea (Figures 6A, B) and P. nicotianae (Figure 6C, D). Oogonia had characteristic ornamented protuberances on the surface and oogonial wall was pigmented to golden-brown with maturation (Figures 6A-D). Many oogonia had a tapered base (Figures 6A, B, D) Oogonial diameter averaged $38.2 \mu \mathrm{m}$. Plerotic oospores averaged $34 \mu \mathrm{m}$ in diameter (Figures 6A-D). All antheridia were amphigynous (Figures 6A-D) and averaged $19.5 \mu \mathrm{m}$ depth and $14.3 \mu \mathrm{m}$ width. Sometimes bicellular antheridia were produced (Figure 6A).

\section{Holotype}

ATCC MYA-4946 (exo-type: 57J3) from irrigation water of a nursery reservoir, Mississippi, USA, February, 2012.

\section{Etymology}

'mississippiae' refers to the state of Mississippi where this new species was isolated.

\section{Habitat}

Irrigation water of an ornamental plant nursery, Mississippi, USA.

\section{Discussion}

This study characterized a novel species of Phytophthora morphologically, physiologically and phylogenetically then named it as $P$. mississippiae. This is the first and critical step to understanding 
Citation: Yang X, Copes WE, Hong C (2013) Phytophthora mississippiae sp. nov., a New Species Recovered from Irrigation Reservoirs at a Plant Nursery in Mississippi. J Plant Pathol Microb 4: 180 doi:10.4172/2157-7471.1000180

the biology, ecology and economic significance of any novel species. The description of $P$. mississippiae will help the first responders in diagnosing the disease caused by this new species. It also will reduce misidentification of high-impact pathogens like P. ramorum [17] and P. kernoviae [35].

Phytophthora mississippiae can be readily distinguished from all known Phytophthora species by its morphological and molecular characters. Within the genus Phytophthora, only 5 species, P. alni [36], $P$. cambivora [6], P. gibbosa [5], P. katsurae [37], and this new species, $P$. mississippiae produce ornamented oogonia with bullate protuberances. P. mississippiae is easily separated from three homothallic species, P. alni, P. gibbosa and P. katsurae $[5,31,36,37]$ by its heterothallism. Both $P$. cambivora and $P$. mississippiae are heterothallic, but they can be separated by the papillation of sporangia and presence of hyphal swellings. P. mississippiae produces both nonpapillate and semipapillate sporangia, while $P$. cambivora produces only nonpapillate sporangia [31]. P. mississippiae also frequently produces catenulate hyphal swellings, while P. cambivora typically does not. Similarly, P. mississippiae can be easily differentiated from other clade 6 species including P. borealis, $P$. thermophila, and P. gonapodyides in cox 1 sequences ( $>30$ bp difference).

Like many other species in clade 6 , the economic importance of P. mississippiae is not known at this point. Many clade 6 species are abundant in natural habitats and frequently recovered from natural water and soil environments, but usually do not cause apparent disease symptoms on plants [38]. Only a few clade 6 species have been found to cause diseases on agricultural and horticultural plants [5]. Examples include $P$. asparagi which causes root rot of asparagus [39] and $P$. megasperma which causes crown rot of hollyhock [8]. A saprophytic lifestyle for many species in this clade may play an important role in decomposing plant debris [38]. Unlike many other clade 6 species initially detected in natural environments, $P$. mississippiae was first recovered from irrigation water in a plant production facility. It is possible that $P$. mississippiae was carried into agricultural irrigation water systems from surrounding habitats through flash flood runoff that occurred in this area during heavy rains. This hypothesis is supported by the fact that this new species was found only in Mississippi but not in any of nursery irrigation systems surveyed in Virginia during the past 14 years and in Alabama during the past 2 years. Nevertheless, investigations into its origin, pathogenicity and host range are warranted.

\section{Acknowledgments}

This research was supported in part by grants from USDA/NIFA (2005-51101 02337, 2010-51181-21140). We thank Mrs. Patricia Richardson for her assistance in maintaining the cultures and submitting PCR products for DNA sequencing during the study. Our thank extends to Mr. Xitong Li for his help with processing and editing figures for this manuscript.

\section{References}

1. Erwin DC, Ribeiro OK (1996) Phytophthora diseases worldwide. APS Press, St. Paul, Minn.

2. Cooke DE, Drenth A, Duncan JM, Wagels G, Brasier CM (2000) A molecular phylogeny of Phytophthora and related oomycetes. Fungal Genet Biol 30: 1732.

3. Kroon LP, Bakker FT, van den Bosch GB, Bonants PJ, Flier WG (2004) Phylogenetic analysis of Phytophthora species based on mitochondrial and nuclear DNA sequences. Fungal Genet Biol 41: 766-782.

4. Blair JE, Coffey MD, Park SY, Geiser DM, Kang S (2008) A multi-locus phylogeny for Phytophthora utilizing markers derived from complete genome sequences. Fungal Genet Biol 45: 266-277.

5. Jung T, Stukely MJ, Hardy GE, White D, Paap T, et al. (2011) Multiple new
Phytophthora species from ITS Clade 6 associated with natural ecosystems in Australia: evolutionary and ecological implications. Persoonia 26: 13-39.

6. Buisman CJ (1927) Root rots caused by Phycomycetes In: University of Utrecht, Willie Commelin Scholten, Netherlands.

7. Ko WH, Ann PJ (1985) Phytophthora humicola, a new species from soil of a citrus orchard in Taiwan. Mycologia 77: 631-636.

8. Drechsler C (1931) A crown-rot of hollyhocks caused by Phytophthora megasperma n. sp. J Wash Acad Sci 21: 513-526.

9. Brasier CM, Cooke DE, Duncan JM, Hansen EM (2003) Multiple new phenotypic taxa from trees and riparian ecosystems in Phytophthora gonapodyides-P. megasperma ITS Clade 6, which tend to be high-temperature tolerant and either inbreeding or sterile. Mycol Res 107: 277-290.

10. Waterhouse GM (1963) Key to the Species of Phytophthora de Bary. Mycological Papers No. 92.

11. Hansen EM, Wilcox WF, Reeser PW, Sutton W (2009) Phytophthora rosacearum and $P$. sansomeana, new species segregated from the Phytophthora megasperma "complex". Mycologia 101: 129-135.

12. Brasier CM, Sanchez-Hernandez E, Kirk SA (2003) Phytophthora inundata sp. nov, a part heterothallic pathogen of trees and shrubs in wet or flooded soils. Mycol Res 107: 477-484

13. Nechwatal J, Bakonyi J, Cacciola SO, Cooke DEL, Jung T, et al. (2013) The morphology, behaviour and molecular phylogeny of Phytophthora taxon Salixsoil and its redesignation as Phytophthora lacustris sp. nov. Plant Pathol 62: $355-369$

14. Aghighi S, Hardy GESJ, Scott JK, Burgess TI (2012) Phytophthora bilorbang sp. nov., a new species associated with the decline of Rubus anglocandicans (European blackberry) in Western Australia. Eur J Plant Pathol 133: 841-855.

15. Man in 't Veld WA, Rosendahl KC, Brouwer H, de Cock AW (2011) Phytophthora gemini sp. nov., a new species isolated from the halophilic plant Zostera marina in the Netherlands. Fungal Biol 115: 724-732.

16. Goheen EM, Hansen EM, Kanaskie A, McWilliams MG, Osterbauer N, et al. (2002) Sudden oak death caused by Phytophthora ramorum in Oregon. Plan Dis 86: 441 .

17. Rizzo DM, Garbelotto M, Davidson JM, Slaughter GW, Koike ST (2002) Phytophthora ramorum as the cause of extensive mortality of Quercus spp. and Lithocarpus densiflorus in California. Plant Dis 86: 205-214.

18. Shearer BL, Crane CE, Cochrane A (2004) Quantification of the susceptibility of the native flora of the South-West Botanical Province, Western Australia, to Phytophthora cinnamomi. Aust J Bot 52: 435-443.

19. Hansen EM (2008) Alien forest pathogens: Phytophthora species are changing world forests. Boreal Environ Res 13: 33-41.

20. Hansen EM, Reeser PW, Sutton W (2012) Phytophthora borealis and Phytophthora riparia, new species in Phytophthora ITS Clade 6. Mycologia 104: 1133-1142.

21. Hong CX, Moorman GW (2005) Plant pathogens in irrigation water: Challenges and opportunities. Crit Rev Plant Sci 24: 189-208.

22. Bouwer H (2002) Integrated water management for the 21st century: Problems and solutions. J Irrig Drain E-Asce 128: 193-202.

23. Hong C, Gallegly ME, Richardson PA, Kong P, Moorman GW (2008) Phytophthora irrigata, a new species isolated from irrigation reservoirs and rivers in Eastern United States of America. FEMS Microbiol Lett 285: 203-211.

24. Hong CX, Gallegly ME, Richardson PA, Kong P, Moorman GW, et al. (2010) Phytophthora hydropathica, a new pathogen identified from irrigation water Rhododendron catawbiense and Kalmia latifolia. Plant Pathol 59: 913-921.

25. Hong C, Richardson PA, Hao W, Ghimire SR, Kong P, et al. (2012) Phytophthora aquimorbida sp. nov. and Phytophthora taxon 'aquatilis' recovered from irrigation reservoirs and a stream in Virginia, USA. Mycologia 104: 1097-1108.

26. Bush EA, Hong CX, Stromberg EL (2003) Fluctuations of Phytophthora and Pythium spp. in components of a recycling irrigation system. Plant Dis 87 1500-1506.

27. Ghimire SR, Richardson PA, Kong P, Hu J, Lea-Cox JD, et al. (2011) Distribution and diversity of Phytophthora species in nursery irrigation reservoir adopting water recycling system during winter months. J Phytopathol 159: 713-719. 
Citation: Yang X, Copes WE, Hong C (2013) Phytophthora mississippiae sp. nov., a New Species Recovered from Irrigation Reservoirs at a Plant Nursery in Mississippi. J Plant Pathol Microb 4: 180 doi:10.4172/2157-7471.1000180

28. Dean CB, Nielsen JD (2007) Generalized linear mixed models: a review and some extensions. Lifetime Data Anal 13: 497-512.

29. Warnes GR, Bolker B, Bonebakker L, Gentleman R, Liaw WHA, et al. (2012) gplots: Various $\mathrm{R}$ programming tools for plotting data In: (Editors: Bolker B. Bonebakker L., Gentleman R., Liaw W.H.A., Lumley T., et al).

30. Ko WH (1978) Heterothallic Phytophthora-evidence for hormonal regulation of sexual reproduction. J Gen Microbiol 107: 15-18.

31. Gallegly ME, Hong CX (2008) Phytophthora: identifying species by morphology and DNA fingerprints. APS Press, St. Paul, Minn.

32. Kong P, Hong C, Richardson PA, Gallegly ME (2003) Single-strandconformation polymorphism of ribosomal DNA for rapid species differentiation in genus Phytophthora. Fungal Genet Biol 39: 238-249.

33. Tamura K, Peterson D, Peterson N, Stecher G, Nei M, et al. (2011) MEGA5 molecular evolutionary genetics analysis using maximum likelihood, evolutionary distance, and maximum parsimony methods. Mol Biol Evol 28: 2731-2739.
34. Tamura K, Nei M (1993) Estimation of the number of nucleotide substitutions in the control region of mitochondrial DNA in humans and chimpanzees. Mo Biol Evol 10: 512-526.

35. Brasier CM, Beales PA, Kirk SA, Denman S, Rose J (2005) Phytophthora kernoviae sp. nov., an invasive pathogen causing bleeding stem lesions on forest trees and foliar necrosis of ornamentals in the UK. Mycol Res 109: 853859.

36. Brasier CM, Kirk SA, Delcan J, Cooke DE, Jung T, et al. (2004) Phytophthora alni sp. nov. and its variants: designation of emerging heteroploid hybrid pathogens spreading on Alnus trees. Mycol Res 108: 1172-1184.

37. Ko WH, Chang HS (1979) Phytophthora katsurae, a new name for P. castaneae Mycologia 71: 840-844.

38. Kroon LP, Brouwer H, de Cock AW, Govers F (2012) The genus phytophthora anno 2012. Phytopathology 102: 348-364.

39. Saude C, Hurtado-Gonzales OP, Lamour KH, Hausbeck MK (2008) Occurrence and characterization of a Phytophthora sp. pathogenic to asparagus (Asparagus officinalis) in Michigan. Phytopathology 98: 1075-1083. 